\title{
EFISIENSI PENGGUNAAN FAKTOR PRODUKSI USAHATANI CABE DI KELURAHAN MARAWAS KECAMATAN TONDANO UTARA KABUPATEN MINAHASA
}

\author{
Juliana R. Mandei \\ Lyndon Pangemanan \\ E. G. Tangkere \\ Novie Wongkar
}

\begin{abstract}
The purpose of this research is to know the efficiency of factors production utilization of the chili farm in Marawas Village Subdistict North Tondano Regency of Minahasa. The research has been carried out for 3 months from Mei 2011 to July 2011. The location was selected by purposive sampling because almost of the Marawas village citizen depend on chili farm, with the number of respond is 40 farmer.

Data were analyzed quantitively utilizing statistical calculation of regression analysis. Primary data obtained are the amount of production, the wide of land, the amount of labor, seed, organic and NPK fertilizer, pesticide dan the growth incentive substance (ZPT).

The result of research showed that the regression model suitable to be researched. From the F-test showed the utilization of the wide of land, the amount of labor, seed, organic and NPK fertilizer, pesticide dan the growth incentive substance (ZPT) have an significant influence toward the amount of production, however, T-test found that the production factors wide of land, the amount of labor and organic fertilizer as separated have an significant influence toward the amount of production. The production's factors the amount of seed, NPK fertilizer dan the growth incentive substance (ZPT) haven't influence toward the amount of production.

The utilization of the factors of production the wide of land, the amount of labor, seed, organic and NPK fertilizer dan the growth incentive substance (ZPT) of the chili farm in Marawas Village were technically efficient but not economically efficient, whereas the utilization of pesticide was not technically and economically efficient. Therefor it is suggested to chili farmer of the Marawas Village Subdistict North Tondano Regency of Minahasa to reduced over pesticide utilization to extermination of chili's pest and desease with other way, which more environment and not contained chemical material, for example manually, mechanical and physical controlling.
\end{abstract}

Keywords: Efficiency, Factors Production, Chili Farm, Marawas Village

\section{PENDAHULUAN}

Keberadaan hortikultura di Indonesia memberikan harapan cerah di sektor pertanian. Perkembangan di pertanian sub sektor hortikultura tersebut memberikan nilai tambah yang sangat berharga bagi kemajuan pertanian di Indonesia. Cabe salah satu komoditas yang termasuk dalam kelompok hortikultura, banyak diusahakan oleh produsen dalam berbagai skala usaha tani ( Santika. A, 1995).
Kecamatan Tondano Utara merupakan daerah yang berpotensi untuk perkembangan Tanaman Hortikultura, salah satunya adalah tanaman Cabe. Berdasarkan data yang di Balai Penyuluhan Pertanian, Perikanan dan Kehutanan (BP3K) Kecamatan Tondano Utara, pada tahun 2010 luas panen sebanyak $135 \mathrm{Ha}$, sedangkan produksi sebanyak 183,83 Ton dengan produktivitas rata-rata 1,36 Ton/Ha. Luas panen, produksi dan produktivitas Cabe dapat dilihat pada Tabel 1. 
Tabel 1. Luas Panen, Produksi dan Produk-tivitas Cabe di Kecamatan Tondano Utara Tahun 2006 - 2010

\begin{tabular}{|c|c|c|c|c|}
\hline No. & Tahun & $\begin{array}{c}\text { Luas } \\
\text { Panen } \\
(\mathrm{Ha})\end{array}$ & $\begin{array}{c}\text { Produk- } \\
\text { si } \\
\text { (Ton) }\end{array}$ & $\begin{array}{c}\text { Produk- } \\
\text { tivitas } \\
\text { (Ton/H } \\
\text { a) }\end{array}$ \\
\hline 1. & 2006 & 128 & 166,40 & 1,30 \\
\hline 2. & 2007 & 131 & 183,40 & 1,40 \\
\hline 3. & 2008 & 129 & 161,25 & 1,25 \\
\hline 4. & 2009 & 132 & 178,20 & 1,35 \\
\hline 5. & 2010 & 135 & 183,83 & 1,36 \\
\hline & $\begin{array}{c}\text { Rata- } \\
\text { Rata }\end{array}$ & 131 & 174.62 & 1,33 \\
\hline
\end{tabular}

Sumber : BP3K Kecamatan Tondano Utara

Dari Tabel 1 dikemukakan bahwa perkembangan produksi Cabe di Kecamatan Tondano Utara antara tahun 2006 - 2010, produksi terbesar berada pada tahun 2007 dengan rata-rata produktivitas per hektarnya sebanyak 1,40 Ton/Ha, dan produksi sebesar 183,40 Ton, sedangkan hasil rata-rata produksi terendah pada tahun 2008 dengan rata-rata produktivitas per hektarnya 1,25 ton/ha dengan produksi 161,25 Ton.

Salah satu Desa / Kelurahan di Kecamatan Tondano Utara yang berpotensi untuk perkembangan tanaman Cabe adalah Kelurahan Marawas. Kelurahan Marawas merupakan wilayah dalam Kecamatan Tondano yang memiliki luas panen terbesar diantara 7 wilayah lainnya. Pada tahun 2010 luas panen tanaman cabe di kelurahan Marawas sebanyak $28 \mathrm{Ha}$, dengan produksi 183,83 Ton, Produktivitas ratarata $1,36 \mathrm{Ton} / \mathrm{Ha}$, sebagaimana dapat dilihat pada tabel 2.

Dalam kegiatan usahatani Cabe, penggunaan faktor produksi dan penerapan teknologi memegang peranan penting. Petani perlu mengetahui faktor-faktor apa saja yang akan digunakan untuk memproduksi Cabe dan juga harus pandai mengadakan pemilihan penggunaan faktor produksi yang ada secara tepat, mengkombinasikan faktor produksi yang ada secara optimal dan efisien, karena produksi yang dihasilkan tergantung pada penggunaan faktorfaktor produksi.
Pada kenyataannya sebagian besar petani Cabe belum memahami bagaimana faktor produksi tersebut digunakan secara efisien. Hal ini disebabkan kurangnya pengetahuan dan keahlian petani dalam mengolah usahataninya tersebut, oleh karena itu penelitian ini penting dilakukan terutama dalam menganalisa penggunaan faktor-faktor produksi usahatani Cabe di Kelurahan Marawas.

Berdasarkan uraian tersebut maka penelitian ini dilakukan dengan tujuan untuk mengetahui efisiensi penggunaan faktor produksi pada usaha tani Cabe di Kelurahan Marawas Kecamatan Tondano Utara. Adapun manfaat dari penelitian ini dapat memberikan informasi bagi petani dalam penggunaan faktor-faktor produksi yang optimal pada usaha tani Cabe.

\section{METODE PENELITIAN}

\section{Waktu dan Tempat Penelitian}

Penelitian ini dilaksanakan selama 3 (tiga) bulan dari persiapan sampai penyusunan laporan yaitu mulai bulan Mei sampai dengan Juni 2011 di di Kelurahan Marawas Kecamatan Tondano Utara Kabupaten Minahasa.

\section{Metodologi Pengumpulan Data}

Metode yang digunakan dalam penelitian ini adalah metode survey dengan menggunakan data primer dan data sekunder. Data primer diperoleh dari wawancara langsung dengan responden. Sedangkan data sekunder diambil dari instansiinstansi yang terkait dengan penelitian ini.

\section{Metode Pengambilan Sampel}

Pengambilan sampel dilakukan dengan menggunakan metode "Simple Random Sampling" dengan jumlah sampel adalah sebanyak 40 petani dari 60 Petani Cabe di Kelurahan Marawas.

\section{Konsep Pengukuran Variabel}

Adapun variable-variabel yang akan diukur serta dugunakan dalam penelitian ini adalah:

1. Produksi, yaitu total produksi cabe yang dicapai petani dalam satu kali musim tanam yang diukur dalam kilogram $(\mathrm{kg})$.

2. Luas lahan, yaitu lahan yang ditanami cabe (ha).

3. Jumlah tenaga kerja yang digunakan selama musim tanam (HOK). 
4. Jumlah benih yang digunakan dalam satu kali musim tanam diukur dalam kilogram $(\mathrm{kg})$.

5. Jumlah pupuk Organik yang digunakan dalam satu kali musim tanam dinyatakan dalam kilogram $(\mathrm{kg})$.

6. Jumlah pupuk NPK yang digunakan dalam satu kali musim tanam dinyatakan dalam kilogram $(\mathrm{kg})$.

7. Pestisida, Jumlah pestisida yang digunakan dalam satu kali musim tanam dinyatakan dalam milliliter ( $\mathrm{ml})$.

8. Zat Perangsang Tumbuh (ZPT), jumlah zat perangsang tumbuh yang digunakan dalam satu kali musim tanam dinyatakan dalam mililiter ( $\mathrm{ml})$.

9. Harga jual produksi, adalah harga jual cabe yang berlaku ditingkat petani dinyatakan dalam rupiah $(\mathrm{Rp})$.

10. Harga input faktor ( $\mathrm{Rp})$

\section{Metode Analisis Data}

Dalam penelitian ini dilakukan analisis regresi berganda dengan model fungsi CobbDouglass untuk melihat hubungan masing-masing faktor produksi terhadap hasil produksi, kemudian dilanjutkan dengan analisis efisiensi.

Secara umum fungsi produksi dapat digambarkan sebagai berikut:

$$
\mathrm{Yi}=\beta_{0} X_{1}^{\beta_{1}} X_{2}^{\beta_{2}} X_{3}^{\beta_{3}} X_{4}^{\beta_{4}} X_{5}^{\beta_{5}} X_{6}^{\beta_{6}} X_{7}^{\beta_{7}} \varepsilon
$$

Dalam bentuk logaritma menjadi:

$$
\begin{aligned}
& \operatorname{Ln} Y_{i}=\operatorname{Ln} \beta_{0}+\operatorname{Ln} \beta_{1} X_{1}+\operatorname{Ln} \beta_{2} X_{2}+\operatorname{Ln} \beta_{3} X_{3}+ \\
& \operatorname{Ln} \beta_{4} X_{4}+\operatorname{Ln} \beta_{5} X_{5}+\operatorname{Ln} \beta_{6} X_{6}+\operatorname{Ln} \beta_{7} X_{7}+\varepsilon
\end{aligned}
$$

Keterangan:

$\mathrm{Y}_{\mathrm{i}}=$ Produksi cabe $(\mathrm{Kg})$

$\mathrm{X}_{1}=$ Luas lahan $(\mathrm{Ha})$

$\mathrm{X}_{2}=$ Tenaga Kerja (HOK)

$\mathrm{X}_{3}=$ Benih $(\mathrm{Kg})$

$\mathrm{X}_{4}=$ Pupuk organik $(\mathrm{Kg})$

$\mathrm{X}_{5}=$ Pupuk NPK $(\mathrm{Kg})$

$\mathrm{X}_{6}=$ Pestisida $(\mathrm{ml})$

$\mathrm{X}_{7}=$ Zat perangsang tumbuh $(\mathrm{ml})$

$\beta_{1}, \beta_{2}, . . \beta_{7}=$ koefisien regresi

\section{Perhitungan Efisiensi Teknis}

Efisiensi teknik dapat diketahui melalui elastisitas produksi. Elastisitas produksi adalah persentase perubahanan dari output sebagai akibat dari persentase perubahan input. Elastisitas produksi dapat diketahui melalui koefisien regresi. Hubungan elastisitas produksi dengan koefisien regresi dapat ditulis sebagai berikut:

$$
\begin{aligned}
\mathrm{EP} & =\frac{\delta y / y}{\delta x_{i} / x_{i}} \\
& =\frac{\delta y}{\delta x_{i}} \frac{x_{i}}{y} \\
& =b_{i} \frac{y}{x_{i}} \frac{x_{i}}{y}=b_{i}
\end{aligned}
$$

$b_{i}$ adalah koefisien regresi dari masing-masing input faktor yang juga menunjukkan elastisitas produksi dan input faktor tersebut. Penggunaan faktor produksi dapat dikatakan efisien apabila elastisitas produksi berada diantara 0 dan 1 atau 1 $>\mathrm{E} \mathrm{P}>0$.

\section{Perhitungan Efisiensi Ekonomis}

Untuk mengerahui syarat kecakupan atau efesiensi ekonomis tiap faktor produksi dapat dilihat dari perbandingan persamaannya adalah:

$$
\frac{N P M x i}{B K M x i}=\frac{\beta i \frac{y}{x i} \cdot H y}{H x i}
$$

Keterangan:

$$
\begin{aligned}
\beta i & =\text { koefisien regresi atau } \\
& \text { elastisitas produksi } \\
\mathrm{Hy} & =\text { harga satuan produk } \\
\mathrm{Hx} & =\text { harga input faktor } \\
\mathrm{Y} & =\text { produk atau output } \\
\mathrm{X}_{\mathrm{i}} & =\text { input faktor } \\
\mathrm{NPM} & =\text { nilai produk marginal } \\
\mathrm{BKM} & =\text { biaya korbanan marginal }
\end{aligned}
$$

Apabila $\frac{N P M x i}{B K M x 1}>1$, maka secara ekonomis penggunaan faktor produksi belum efisien, dalam arti penggunaan faktor produksi masih bisa ditambah.

Apabila $\frac{N P M x i}{B K M x 1}=1, \quad$ maka secara ekonomis penggunaan faktor produksi sudah efisien. 
Apabila $\frac{N P M x i}{B K M x 1}<1, \quad$ maka secara ekonomis penggunaan faktor produksi tidak efisien, dalam arti penggunaan faktor produksi sudah berlebihan.

\section{Uji Penyimpangan Asumsi Klasik}

Uji penyimpangan asumsi klasik meliputi:

a. Uji Normalitas. Uji ini dilakukan untuk melihat apakah semua data terdistribusi dengan normal atau tidak. Uji normalitas data melalui uji grafik profitability plot, yaitu plot yang membandingkan distribusi kumulatif dari data yang sesungguhnya dengan distribusi kumulatif dari data distribusi normal (Ghozali, 2001).

b. Uji Multikolinieritas. multikolinieritas sempurna adalah suatu pelanggaran terhadap asumsi bahwa tidak ada hubungan sempurna antar variabel dalam sebuah persamaan regresi, namun multikolinieritas sempurna jarang terjadi dan jikapun ada mudah untuk dihindari.

Ada beberapa cara untuk mendeteksi multikolinieritas, yaitu:

1. Koefisien korelasi sederhana yang tinggi.

2. High Variance Inflation Factors (VIF). Apabila angka VIF dari suatu variabel melebihi 10, maka semakin besar dampak multikolinieritas.

c. Uji Otokorelasi. Uji ini merupakan pelanggaran asumsi klasik yang menyatakan bahwa dalam pengamatan-pengamatan yang berbeda tidak terdapat korelasi antar error term.

Untuk mendeteksi adanya otokorelasi digunakan uji $d$ Durbin - Watson.

Pengambilan keputusan ada tidaknya otokorelasi melalui uji d Durbin- Watson, adalah bila :

1. $d>\left(d_{\mathrm{U}}\right)$ maka koefisien otokorelasi sama dengan nol, ini berarti tidak ada otokorelasi.

2. $d<\left(d_{\mathrm{L}}\right)$ maka koefisien otokorelasi lebih besar daripada nol, ini berarti ada otokorelasi positif.

3. $d_{\mathrm{L}} \leq d \leq d_{\mathrm{U}}$ maka tidak tersimpulkan.

4. $d>\left(4-d_{\mathrm{L}}\right)$ maka koefisien otokorelasi lebih kecil dari nol, ini berarti ada korelasi negatif.
5. $d<\left(4-d_{\mathrm{L}}\right)$ maka koefisien otokorelasi sama dengan nol, ini berarti tidak ada otokorelasi.

6. (4- $\left.d_{\mathrm{U}}\right) \leq d \leq\left(4-d_{\mathrm{L}}\right)$ maka hasilnya tidak dapat disimpulkan.

d. Uji Heteroskedastisitas. Asumsi lain dari model regresi linier klasik adalah bahwa varian residual bersifat konstan atau homoskedastisitas. Pada umumnya sering terjadi pada model-model yang menggunakan data cross section daripada data time series.

Untuk mendeteksi heteroskedastisitas dalam penelitian ini digunakan metode grafik nilai-nilai residu. Suatu model mengandung heteroskedastisitas apabila nilai residunya membentuk pola sebaran yang meningkat atau menurun. Jika sebarannya acak maka model tidak mengandung heteroskedastisitas.

\section{HASIL PENELITIAN DAN PEMBAHASAN}

\section{Faktor-Faktor Produksi Usahatani Cabe \\ 1. Luas Lahan}

Lahan merupakan faktor produksi yang penting bagi setiap usahatani, karena lahan merupakan wadah untuk menanam komoditi yang ingin diusahakan oleh petani. Luas lahan untuk usahatani cabe di Kelurahan Marawas dapat dilihat pada Tabel 2.

Tabel 2. Luas Lahan Usahatani Cabe di Kelurahan Marawas

\begin{tabular}{|c|l|c|c|}
\hline No. & $\begin{array}{c}\text { Luas Lahan } \\
(\mathrm{Ha})\end{array}$ & $\begin{array}{c}\text { Jumlah } \\
\text { Petani } \\
\text { (Orang) }\end{array}$ & $\begin{array}{c}\text { Persentase } \\
(\%)\end{array}$ \\
\hline 1. & $<0,5$ & 5 & 12,50 \\
2. & $0,5-0,75$ & 26 & 65,00 \\
3. & $0,80-1,00$ & 8 & 20,00 \\
4. & $>1$ & 1 & 2,50 \\
\hline & \multicolumn{1}{|c|}{ Jumlah } & 40 & 100,00 \\
\hline
\end{tabular}

Tabel 2 memperlihatkan bahwa sebagian besar petani mengelolah usahatani Cabe pada luasan $0,5-0,75$ ha yaitu sebanyak 65 persen. Dan hanya 2,50 persen petani yang berusahatani cabe pada luas lahan lebih dari 1 ha. 
Rata-rata penggunaan lahan pada usahatani cabe di Kelurahan Marawas adalah 0,66 hektar. Status kepemilikan lahan petani cabe sebagian besar adalah pemilik, namun ada juga yang menggarap lahan milik petani lain atau menyewa dengan biaya sewa Rp 1.000.000,- per hektar.

\section{Tenaga Kerja}

Ada 2 macam tenaga kerja yang dipakai dalam usahatani yaitu tenaga kerja manusia dan tenaga kerja hewan. Pada usahatani Cabe di Kelurahan Marawas hanya menggunakan tenaga kerja manusia sejak awal penggarapan, proses tanam sampai pada hasil panen. Sebagian besar petani Cabe menggunakan tenaga kerja yang berasal dari keluarga, namun ada beberapa tahap yang juga mengambil tenaga kerja dari luar keluarga, seperti pada tahap awal penggarapan dan tahap panen terutama jika hasil panen usahatani-nya sangat banyak. Rata-rata jumlah tenaga kerja yang digunakan adalah sebanyak 94,10 HOK per hektar (Lampiran 3).

Upah tenaga kerja yang berlaku di Kelurahan Marawas berbeda antara tenaga kerja pria dan wanita. Upah tenaga kerja pria adalah $\operatorname{Rp} 60.000$,dan upah tenaga kerja wanita adalah Rp 50.000,- . Pada penelitian ini untuk penentuan upah tenaga kerja menggunakan upah tenaga kerja pria, sehingga satuan yang digunakan adalah upah berdasarkan hari kerja setara pria.

\section{Benih}

Benih merupakan faktor produksi yang penting karena merupakan cikal bakal tanaman Cabe. Benih disemai terlebih dulu sebelum penanaman. Benih yang diperoleh oleh petani Cabe berasal dari hasil produksi Cabe yang telah disisihkan, namun ada juga yang diperoleh dengan cara membeli. Adapun harga benih adalah Rp 100.000,- per kg.

Rata-rata jumlah benih yang digunakan pada usahatani cabe di Kelurahan Marawas adalah 0,87 $\mathrm{kg} / \mathrm{ha}$.

\section{Pupuk}

Sebagian besar petani Cabe di Kelurahan Marawas memberikan 2 jenis pupuk yaitu pupuk organik dan pupuk NPK. Adapun harga dari pupuk organik adalah $\mathrm{Rp} 1.000,-$ per $\mathrm{kg}$, sedangkan harga pupuk NPK adalah urea Rp
1.600,- per kg, SP $36 \quad$ Rp 2.000,- per kg dan Phonska Rp 2.300 per kg.

Rata-rata pupuk organik digunakan sebanyak 461,69 kg/ha dan pupuk NPK sebanyak $128,73 \mathrm{~kg} / \mathrm{ha}$.

\section{Pestisida}

Pestisida diberikan dalam rangka membasmi hama dengan cara melalui penyemprotan. Jenis pestisida yang dipakai adalah Kurakron yang berharga Rp 28.000/250 ml, Amistarto p yang berharga $\mathrm{Rp} 50.000,-/ 100 \mathrm{ml}$ dan Decis yang berharga Rp 25.000/100 ml. Rata-rata pemberian pestisida pada usahatani Cabe di Kelurahan Marawas adalah sebanyak 135,35 ml/ha.

\section{Zat Perangsang Tumbuh (ZPT)}

Dalam rangka mempercepat pertumbuhan tanaman cabe, petani menggunakan Zat Perangsang Tumbuh (ZPT). Rata-rata jumlah ZPT yang diberikan oleh petani Cabe di Kelurahan Marawas adalah sebanyak 260,05 ml per hektar (Lampiran 3). Adapun harga ZPT adalah Rp $65.000,-/ 250 \mathrm{ml}$.

\section{Produksi Usahatani Cabe}

Produksi usahatani cabe di Kelurahan Marawas berkisar antara 800 - $2000 \mathrm{~kg}$ per hektarnya. Pada hasil penelitian yang terangkum pada tabel 12 memperlihatkan bahwa dari 40 petani responden, 20 orang petani atau 50 persen menghasilkan produksi cabe berjumlah 1000 $1500 \mathrm{~kg}$ per hektar. Dilanjutkan dengan jumlah petani cabe yang menghasilkan $>1500 \mathrm{~kg}$ per hektar yaitu 16 orang petani atau 40 persen. Sisanya 4 orang petani atau 10 persen menghasilkan produksi cabe sebanyak kurang dari $1000 \mathrm{~kg}$ per hektar.

Tabel 3. Produksi Usahatani Cabe di Kelurahan Marawas

\begin{tabular}{|c|c|c|c|}
\hline No. & $\begin{array}{c}\text { Jumlah } \\
\text { Produksi } \\
(\mathrm{Kg} / \mathrm{Ha})\end{array}$ & $\begin{array}{c}\text { Jumlah } \\
\text { Petani } \\
(\text { Orang) }\end{array}$ & $\begin{array}{c}\text { Persentase } \\
(\%)\end{array}$ \\
\hline 1. & $<1000$ & 4 & 10 \\
2. & $1000-1500$ & 20 & 50 \\
3. & $>1500$ & 16 & 40 \\
\hline & Jumlah & 40 & 100 \\
\hline
\end{tabular}


Harga jual hasil produksi pada usahatani cabe berbeda-beda tergantung dari lokasi penjualan cabe yang dilakukan oleh petani. Harga produksi yang dijual langsung ke pasar tentu akan berbeda dengan harga produksi yang dijual kepada pedagang pengumpul.

Biasanya petani lebih tertarik untuk menjual kepada pedagang pengumpul. Hal tersebut disebabkan petani tidak perlu lagi memikirkan biaya-biaya yang akan keluar seperti biaya sewa kendaraan, biaya buruh dan biaya lainnya, sebab pedagang pengumpul mendatangi langsung petani ke lokasi usahataninya.

Kisaran harga jual produksi cabe di Kelurahan Marawas pada saat penelitian dilakukan adalah Rp 30.000,- sampai dengan Rp 40.000,- per kg.

\section{Hasil Analisis Fungsi Produksi Cabe}

Untuk melihat hubungan antara faktor produksi dengan produksi, maka dilakukan pendugaan terhadap fungsi produksi. Pendugaan terhadap fungsi produksi dilakukan dari data produksi cabe $(\mathrm{Y})$ luas lahan $(\mathrm{X} 1)$, tenaga kerja (X2), benih (X3), pupuk organik (X4), pupuk NPK (X5), pestisid (X6) dan zat perangsang tumbuh (X7). Hubungan tersebut dijelaskan pada analisis regresi dari fungsi, seperti terlihat pada Tabel 4.

Tabel 4. Hasil Analisis Regresi Fungsi produksi Cabe

\begin{tabular}{|l|c|c|l|}
\hline Prediktor & Koefisien & $\begin{array}{c}\text { Statistik- } \\
\mathrm{t}\end{array}$ & $\mathrm{P}$ \\
\hline Konstanta & 1.722 & 1.57 & 0.126 \\
Ln X1 & 0.442 & 3.77 & $0.001^{*}$ \\
Ln X2 & 0.808 & 2.70 & $0.011^{*}$ \\
Ln X3 & 0.014 & 0.14 & 0.893 \\
Ln X4 & 0.239 & 2.46 & $0.020^{* *}$ \\
Ln X5 & 0.129 & 1.16 & 0.255 \\
Ln X6 & -0.071 & 0.94 & 0.354 \\
Ln X7 & 0.089 & 0.59 & 0.559 \\
\hline \multicolumn{4}{|l}{} \\
\hline
\end{tabular}

Secara statistik model persamaan yang berhasil dibangun dapat dinyatakan sangat signifikan, oleh karena F-Statistik yaitu sebesar 28,54 yang signifikan pada taraf kepercayaan $99 \%$ atau $\alpha=1 \%$. Ini menandakan bahwa secara bersama-sama penggunaan faktor produksi luas lahan, tenaga kerja, benih, pupuk, pestisida, Dan
Zat Perangsang Tumbuh (ZPT), mempunyai pengaruh yang sangat nyata terhadap produksi Cabe.

Besarnya Koefisien Determinasi $\left(\mathrm{R}^{2}\right)$ sebesar $86,2 \%$ yang berarti bahwa variasi produksi cabe sekitar 86,2\% disebabkan karena variasi dari penggunaan luas lahan, tenaga kerja, benih, pupuk, pestisida, Zat Perangsang Tumbuh (ZPT), sedangkan sisanya sebanyak 13,8\% disebabkan karena faktor-faktor lain yang tidak disertakan dalam model.

Selanjutnya secara parsial terlihat dalam model bahwa variabel luas lahan, tenaga kerja dan pupuk organik dapat dinyatakan signifikan secara statistik, oleh karena berdasarkan pada uji $\mathrm{T}$ statistik diperoleh bahwa pada variabel luas lahan dan tenaga kerja nilai P masing-masing 0,001 dan 0,011 yang lebih kecil dari $\alpha 1 \%$. Pupuk organik memperoleh nilai $\mathrm{P} 0,02$ yang lebih kecil dari $\alpha$ $5 \%$. Hal ini berarti bahwa variabel luas lahan dan tenaga kerja dan berpengaruh sangat nyata terhadap produksi cabe pada tingkat kepercayaan $99 \%$, sedangkan pupuk organik berpengaruh sangat nyata terhadap produksi cabe pada tingkat kepercayaan 95\%. Hasil estimasi juga menunjukkan bahwa nilai koefisien regresi variabel luas lahan, tenaga kerja dan pupuk organik bertanda positif, yang berarti ketiga variabel tersebut berpengaruh positif terhadap produksi cabe atau dengan kata lain peningkatan luas lahan, tenaga kerja dan pupuk organik akan mengakibatkan produksi Cabe semakin meningkat.

Variabel benih, pupuk NPK, pestisida dan Zat Perangsang Tumbuh (ZPT) tidak berpengaruh nyata terhadap produksi Cabe. Hal ini diduga kemungkinan karena persemaian benih yang kurang dan penggunaan pupuk NPK, pestisida dan Zat Perangsang Tumbuh (ZPT) yang tidak sesuai dengan dosis yang dianjurkan. Rata-rata penggunaan benih per hektar adalah $0,87 \mathrm{~kg}$ dan rata-rata penggunaan pupuk NPK adalah 128,73 $\mathrm{kg}$, pestisida adalah $135,35 \mathrm{~kg}$ dan ZPT 260,05 $\mathrm{ml}$.

\section{Uji Asumsi Klasik}

Hasil dari pengujian asumsi-asumsi klasik terhadap model regresi penelitian ini didapati bahwa model regresi penelitian ini tidak menyimpang dari asumsi-asumsi klasik, sehingga 
Analisis regresi yang dihasilkan layak untuk digunakan.

\section{a. Uji Normalitas}

Pada grafik normal probability plot berikut ini, titik-titik menyebar disekitar diagonal. Hal ini berarti residual tersebut terdistribusi dengan normal.

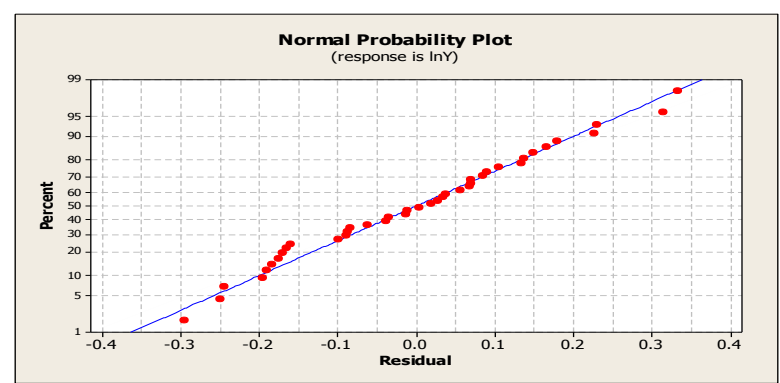

Gambar 1. Normal Probability Plot Hasil Analisis Regresi

\section{b. Uji Multikolinieritas}

Fungsi produksi yang diestimasikan tidak menunjukkan adanya indikasi pelanggaran asumsi multikolinieritas. Hal tersebut ditunjukkan nilai VIF yang diperoleh menunjukkan tidak ada variabel yang memiliki nilai diatas 5 .

Tabel 5. Nilai VIF (Variance Inflaction Factor)

\begin{tabular}{|l|c|}
\hline \multicolumn{1}{|c|}{ Variabel } & Nilai VIF \\
\hline Luas Lahan & 2,803 \\
Tenaga Kerja & 3,958 \\
Benih & 1,802 \\
Pupuk Organik & 1,727 \\
Pupuk NPK & 2,500 \\
Pestisida & 1,701 \\
ZPT & 1,931 \\
\hline
\end{tabular}

\section{c. Uji Autokorelasi}

Tabel Durbin-Watson dengan tingkat signifikansi $1 \%$, dengan $\mathrm{n}=40$ dan $\mathrm{k}$ (variabel bebas $)=7$ diperoleh nilai $\mathrm{d}_{\mathrm{L}}=0,946$ dan $\mathrm{d}_{\mathrm{U}}=$ 1.724. Nilai Dw hit sebesar 1,74255 lebih besar dari nilai $\mathrm{d}_{U}$, ini berarti bahwa model regresi tersebut tidak ada otokorelasi.

\section{d. Uji Heteroskedastisitas}

Berdasarkan grafik scatter plot, yang memperlihatkan bahwa titik-titik yang terdapat pada grafik tidak membentuk pola tertentu. Ini berarti model regresi pada penelitian ini tidak terkena gejala heteroskedastisitas.

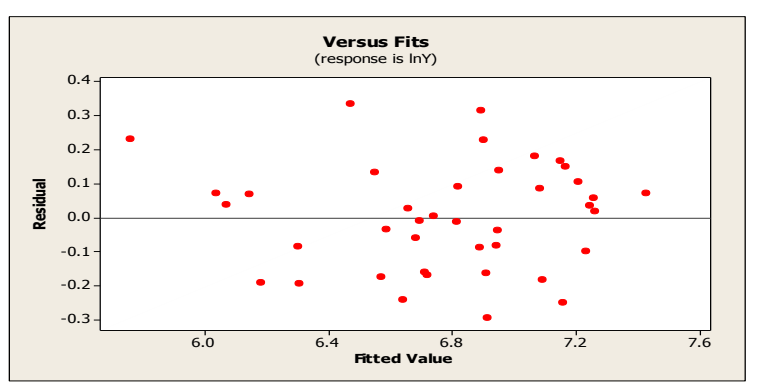

Gambar 2. Scatter Plot Hasil Analisis Regresi

\section{Efisiensi Penggunaan Faktor Produksi Cabe}

1. Efisiensi Teknik (Syarat Keharusan)

Efisiensi teknik penggunaan faktor produksi dapat terpenuhi yaitu apabila elastisitas produksi berada diantara nol dan satu, atau dalam kurva produksi berada pada daerah II. Hasil pendugaan fungsi produksi Cobb-Douglass akan menghasilkan koefisien regresi yang juga menunjukkan besaran elastisitas produksi (Soekartawi, 1989)

Besarnya elastisitas produksi (Ep) dan efisiensi teknik (syarat keharusan) tiap faktor produksi dapat dilihat pada Tabel 6 berikut ini.

Tabel 6. Elastisitas Produksi dan Efisiensi Teknik (Syarat Keharusan)

\begin{tabular}{|l|c|l|}
\hline \multicolumn{1}{|c|}{ Variabel } & $\begin{array}{c}\text { Elastisitas } \\
\text { Produksi }\end{array}$ & $\begin{array}{c}\text { Efisiensi Teknik } \\
\text { (Syarat } \\
\text { Keharusan) }\end{array}$ \\
\hline Luas Lahan & 0,442 & Memenuhi \\
Tenaga Kerja & 0,808 & Memenuhi \\
Benih & 0,014 & Memenuhi \\
Pupuk Organik & 0,024 & Memenuhi \\
Pupuk NPK & 0,129 & Memenuhi \\
Pestisida & $-0,071$ & TidakMemenuhi \\
ZPT & 0,089 & Memenuhi \\
\hline
\end{tabular}

Penjelasan efisiensi teknik (syarat keharusan) pada tiap-tiap faktor produksi adalah sebagai berikut:

a. Lahan

Nilai Nilai koefisien regresi variabel lahan adalah 0,442, yang juga merupakan elastisitas produksi lahan. Besarnya elastisitas produksi ini 
menunjukkan bahwa setiap penambahan lahan sebesar 1\%, "cateris paribus", maka akan memberikan tambahan produksi sebesar $0,442 \%$. Nilai elastisitas produksi faktor produksi lahan bernilai lebih besar dari nol dan lebih kecil dari satu $(0<\mathrm{Ep}<1)$, ini menunjukkan bahwa penggunaan lahan sudah berada pada daerah produksi yang rasional (daerah II). Jadi luas lahan telah memenuhi efisiensi teknik (syarat keharusan).

\section{b. Tenaga Kerja}

Nilai koefisien regresi atau elastisitas produksi variabel lahan adalah 0,808 . Ini berarti bahwa setiap penambahan tenaga kerja sebesar $1 \%$ "cateris paribus", maka akan memberikan tambahan produksi sebesar $0,808 \%$. Penggunaan faktor produksi tenaga kerja telah berada pada daerah rasional (daerah II), Jadi Penggunaan tenaga kerja telah memenuhi efisiensi teknik (syarat keharusan).

\section{c. Benih}

Nilai elastisitas produksi variabel benih yang bisa dilihat dari nilai koefisien regresi yang diperoleh adalah sebesar 0,014, menandakan bahwa setiap penambahan benih sebesar $1 \%$ "cateris paribus", maka akan meningkatkan produksi cabe sebesar $0,014 \%$. Penggunaan benih berada pada daerah produksi yang rasional (daerah II). Jadi jumlah benih telah memenuhi efisiensi teknik (syarat keharusan).

\section{d. Pupuk Organik}

Nilai koefisien regresi atau elastisitas produksi variabel pupuk organik adalah 0,024. Ini berarti bahwa setiap penambahan pupuk organik sebesar $1 \%$ "cateris paribus", maka akan memberikan tambahan produksi sebesar $0,024 \%$.

Penggunaan faktor produksi pupuk organik telah berada pada daerah rasional (daerah II), ini terlihat dari elastisitas produksi yang bernilai lebih besar dari nol dan lebih kecil dari satu $(0<$ Ep $<1)$. Penggunaan pupuk organik telah memenuhi efisiensi teknik ( syarat keharusan).

\section{e. Pupuk NPK}

Nilai koefisien regresi variabel pupuk NPK adalah 0,129, yang juga merupakan elastisitas produksi pupuk NPK. Besarnya elastisitas produksi ini menunjukkan bahwa setiap penambahan lahan sebesar 1\% "cateris paribus", maka akan meningkatkan produksi sebesar $0,129 \%$. Penggunaan pupuk NPK berada pada daerah produksi yang rasional (daerah II). Jadi jumlah pupuk NPK telah memenuhi efisiensi teknik (syarat keharusan).

\section{f. Pestisida}

Nilai elastisitas produksi variabel pestisida yang bisa dilihat dari nilai koefisien regresi yang diperoleh adalah sebesar $-0,071$, menandakan bahwa setiap penambahan pestisida sebesar $1 \%$ "cateris paribus", maka akan menurunkan produksi sebesar $0,0114 \%$. Penggunaan pestisida berada pada daerah produksi yang irrasional (daerah III), jadi penggunaan pestisida tidak memenuhi efisiensi teknik (syarat keharusan).

\section{g. Zat Perangsang Tumbuh}

Nilai koefisien regresi variabel zat perangsang tumbuh (ZPT) adalah 0,089, yang juga merupakan elastisitas produksi zat perangsang tumbuh (ZPT). Besarnya elastisitas produksi ini menunjukkan bahwa setiap penambahan zat perangsang tumbuh (ZPT) sebesar $1 \%$ "cateris paribus", maka akan menaikkan produksi sebesar $0,089 \%$. Penggunaan ZPT berada pada daerah produksi yang rasional (daerah II). Jadi zat perangsang tumbuh (ZPT) telah memenuhi efisiensi teknik (syarat keharusan).

\section{Efisiensi Ekonomi (Syarat Kecukupan)}

Besarnya produk marginal (PM), nilai produk marginal (NPM) dan biaya korbanan marginal (BKM) dapat dilihat padaTabel 7. Tabel 7 menunjukkan bahwa perbandingan antara NPM dan BKM dari faktor-faktor produksi tidak ada satupun yang sama dengan satu. Hal ini berarti penggunaan faktor-faktor produksi tersebut tidak memenuhi syarat kecukupan (belum efisien secara ekonomi). 
Tabel 7. Hasil perhitungan PM, NPM, BKM dan perbandingan NPM dan BKM

\begin{tabular}{|l|r|r|r|r|r|}
\hline Faktor Produksi & \multicolumn{1}{|c|}{ Y/Xi } & \multicolumn{1}{|c|}{ PM } & \multicolumn{1}{c|}{ NPM } & \multicolumn{1}{c|}{ BKM } & NPM/BKM \\
\hline Lahan & 1462,69 & 646,51 & 19395239,29 & $1,000,000$ & 19.395 \\
Tenaga Kerja & 15,54 & 12,56 & 376788,07 & 60,000 & 6.280 \\
Benih & 1671,75 & 23,40 & 702134,20 & 100,000 & 7.021 \\
Pupuk Organik & 3,17 & 0,08 & 2271,52 & 1,000 & 2.272 \\
Pupuk NPK & 11,36 & 1,47 & 43972,09 & 5,000 & 8.794 \\
Pestisida & 10,81 & $(0,76)$ & $(22953,16)$ & 34,000 & -0.675 \\
ZPT & 5,62 & 0,50 & 15017.927 & 68,000 & 0.221 \\
\hline
\end{tabular}

a. Lahan

Besaran produk marginal lahan sebesar 646.508 yang berarti bahwa setiap penambahan luas lahan garapan dalam usahatani cabe sebesar 1 ha akan meningkatkan produksi cabe sebesar $646.508 \mathrm{~kg}$. Nilai produk marginal (NPM) dari faktor produksi lahan adalah 19.395.239,286. Hasil perbandingan NPM dan BKM menunjukkan secara ekonomis penggunaan faktor produksi belum efisien dalam arti faktor produksi lahan masih bisa ditambah.

\section{b. Tenaga Kerja}

Besaran produk marginal tenaga kerja sebesar 12,56 yang berarti bahwa setiap penambahan jumlah tenaga kerja dalam usahatani cabe sebesar 1 HKSP akan meningkatkan produksi cabe sebesar $12,56 \mathrm{~kg}$. Nilai produk marginal (NPM) dari faktor produksi tenaga kerja adalah 376.788,072. Hasil perbandingan NPM dan BKM secara ekonomis penggunaan faktor produksi belum efisien dalam arti penggunaan faktor produksi tenaga kerja masih bisa ditambah.

\section{c. Benih}

Besaran produk marginal benih sebesar 23,404 yang berarti bahwa setiap penambahan jumlah benih dalam usahatani cabe sebesar $1 \mathrm{~kg}$ akan meningkatkan produksi cabe sebesar $23,404 \mathrm{~kg}$. Nilai produk marginal (NPM) dari faktor produksi benih adalah 702.134,200. Hasil perbandingan NPM dan BKM secara ekonomis penggunaan faktor produksi belum efisien dalam arti penggunaan faktor produksi benih masih bisa ditambah.

\section{d. Pupuk Organik}

Besaran produk marginal pupuk organik sebesar 0,076 yang berarti bahwa setiap penambahan jumlah pupuk organik dalam usahatani cabe sebesar $1 \mathrm{~kg}$ akan meningkatkan produksi cabe sebesar $0,076 \mathrm{~kg}$. Nilai produk marginal (NPM) dari faktor produksi tenaga kerja adalah 2.271,519. Hasil perbandingan NPM dan BKM secara ekonomis penggunaan faktor produksi belum efisien dalam arti penggunaan faktor produksi pupuk organik masih bisa ditambah.

\section{e. Pupuk NPK}

Besaran produk marginal pupuk NPK sebesar 1,466 yang menandakan bahwa setiap penambahan jumlah pupuk NPK dalam usahatani cabe sebesar $1 \mathrm{~kg}$ akan meningkatkan produksi cabe sebesar $1,466 \mathrm{~kg}$. Nilai produk marginal (NPM) dari faktor produksi pupuk NPK adalah 43.972,092. Hasil perbandingan NPM dan BKM secara ekonomis penggunaan faktor produksi belum efisien dalam arti penggunaan faktor produksi pupuk NPK masih bisa ditambah.

\section{f. Pestisida}

Besaran produk marginal pestisida sebesar -0,765 menandakan bahwa setiap penambahan jumlah pestisida dalam usahatani cabe sebesar 1 $\mathrm{ml}$ akan menurunkan produksi cabe sebesar 0,765 $\mathrm{kg}$. Nilai produk marginal (NPM) dari faktor 
produksi pestisida adalah -22.953,165. Hasil perbandingan NPM dan BKM secara ekonomis penggunaan faktor produksi tidak efisien lagi dalam arti penggunaan faktor produksi pestisida sudah berlebihan, sehingga harus dikurangi.

\section{g. Zat Perangsang Tumbuh (ZPT)}

Besaran produk marginal ZPT sebesar 0,501 menandakan bahwa setiap penambahan jumlah ZPT dalam usahatani cabe sebesar $1 \mathrm{ml}$ akan meningkatkan produksi cabe sebesar $0,501 \mathrm{~kg}$. Nilai produk marginal (NPM) dari faktor produksi tenaga kerja adalah 15.071,927. Hasil perbandingan NPM dan BKM secara ekonomis faktor produksi belum efisien dalam arti penggunaan faktor produksi ZPT masih bisa ditambah.

\section{KESIMPULAN DAN SARAN}

\section{Kesimpulan}

1. Penggunaan faktor produksi luas lahan, tenaga kerja, benih, pupuk, pestisida, dan zat perangsang tumbuh (ZPT) secara bersamasama berpengaruh nyata terhadap produksi cabe di Kelurahan Marawas.

2. Secara terpisah faktor produksi yang berpengaruh nyata terhadap produksi cabe adalah luas lahan, tenaga kerja, dan pupuk organik. Sedangkan yang tidak berpengaruh nyata adalah faktor produksi benih, pupuk NPK, pestisida dan zat perangsang tumbuh (ZPT).

3. Penggunaan faktor produksi luas lahan, tenaga kerja, pupuk organik, pupuk NPK dan zat perangsang tumbuh (ZPT) pada usahatani cabe di Kelurahan Marawas sudah efisien secara teknis namun secara ekonomis belum efisien. Sedangkan penggunaan pestisida tidak efisien secara teknis maupun ekonomis.

\section{Saran}

Dari kesimpulan yang diuraikan disarankan kepada Petani Cabe di Kelurahan Marawas Kecamatan Tondano Utara Kabupaten Minahasa untuk mengurangi penggunaan pestisida yang berlebihan dalam membasmi hama dan penyakit pada tanaman cabe dengan menggunakan cara lain yang lebih ramah lingkungan dan tidak mengandung bahan kimiawi, diantaranya adalah pengendalian secara manual, mekanik dan fisik.

\section{DAFTAR PUSTAKA}

Anonimous, 2010. Budidaya Dan Bisnis Cabe. PT. Agromedio Pustaka.

Barthos. B, 1990. Manajemen Sumber Daya Manusia. Bumi Aksara Jakarta.

Beattie, B.R. dan Taylor, 1994. Ekonomi Produksi. Gaja Mada Uneversity Press. Yogyakarta.

Bishop, C.E and Toussaint, W.D. 1979. Pengantar Analisa Ekonomi Pertanian. Terjemahan Wisnu Aji, MA, Harsono SE dan MA. Supamoko.

Daniel, Moehar, MS.2004. Pengantar Ekonomi Pertanian. Bumi Aksara. Jakarta

Heady. E.D and J. L. Dilon, 1969. Agriculture Production Function. IOWA State Univercity Press. AMES IOWA.

Komarudin, 1991. Asas-Asas Manajemen Produksi. Bumi Aksara. Jakarta.

Mosher, A.T., 1991. Menggerakan dan Membangun Pertanian. Yasaguna. Jakarta.

Mubyarto, 1982. Pengantar Ilmu Pertanian. LP3ES. Yogyakarta.

Pakasi, P., 1986. Pengaruh Faktor-faktor Sosial Ekonomi Petani Terhadap Teknologi Baru Padi Sawah Di Kecamatan Dumoga Kabupaten Bolaang Mongondow. Fakultas Pertanian UNSRAT Manado.

Santika, A. 1995. Agribisnis Cabe. Penebar Swadaya. Surabaya.

Sitompul, N. L., 2007. Analisis Pengaruh Investasi dan Tenaga Kerja terhadap PDRB Sumatera Utara. Tesis. Sekolah Pascasarjana Universitas Sumatera Utara. Medan.

Soekartawi,1989.Agribisnis teori dan Aplikasinya. PT.Raja Grafindo Persada. Jakarta.

1995. Analisis Usahatani. Universitas Indonesia. Press Jakarta. 
2001. Teori Ekonomi Produksi. CV.

Rajawali. Jakarta.

, 2005. Prinsip Dasar Ekonomi

Pertanian. PT. Raja Grafindo Persada. Jakarta.

Teken I.B. dan Asnawi S., 1995. Teori Ekonomi Mikro. ITB. Bogor. 